\title{
Effect of Simultaneous Cystocele Repair On Transobturator Tape In Patients With Stress Urinary Incontinence
}

\section{Stres Tipi Idrar Kaçırması Olan Hastalarda Eş Zamanlı Sistosel Onarımının Transobturator Tape Sonuçları Üzerine Etkisi}

\author{
Ozan Bozkurt, Serdar Çelik, Kaan Çömez, Ömer Demir, Adil Esen
}

Dokuz Eylül University Faculty of Medicine, Department of Urology, Izmir, Turkey

\section{What's known on the subject? and What does the study add?}

Currently, midurethral sling operations are the first-line operations in surgical treatment of stress urinary incontinence (SUI) with their high success rates and minimally invasive properties. It was observed that simultaneous prolapsus surgery did not have a marked effect on the operation results in most of the previous studies in which mostly tension-free vaginal tape (TVT) was evaluated. In addition, there are publications reporting that complications increased. Since there is no sufficient data related with cystocele repair performed simultaneously with TOT in patients with SUI and accompanying pelvic organ prolapsus, this study will contribute to the literature on this subject.

\section{ABSTRACT}

Objective

In this study, the effect of cystocele repair performed simultaneously with transobturator tape (TOT) on the results of operation was evaluated in patients with stress urinary incontinance (SUI) and pelvis organ prolapsus (POP).

\section{Materials and Methods}

The data of 103 patients who had SUI and cystocele between 2006 and 2012 were evaluated retrospectively. The patients who underwent only TOT was classified as group 1 and the patients who underwent cystocele repair simulatenously with TOT were classified as group 2. The patients in group 2 were divided as group 2a (low grade cystocele (grade 1 and 2)) and group $2 b$ (high grade (grade 3) cystocele ). The age, number of normal deliveries, pad test, cystocele grade, post-operative complications and preop International Consultation on Incontinence Questionnaire-Short Form (ICIQ-SF) forms were evaluated from the patient files. All patients were questioned by ICIQ-SF in terms of the final continence status. The groups were compared in terms of the above-mentioned parameters.

\section{Results}

It was observed that there was no significant difference between group 1 and group 2 in terms of preoperative IClQ-SF scores (16.06 \pm 0.34 and $16.82 \pm 0.42$, respectively) and demographic data at the baseline. It was observed that the postoperative ICIQ-SF scores decreased markedly in both groups $(3.28 \pm 0.78$ and $5.41 \pm 1.21$, respectively, $p<0.01)$. While there was no difference in preoperative ICIQ-SF values in the patients in group $2 b$ in comparison with the patients in group $2 \mathrm{a}$, the postoperative ICIQ-SF score

\section{ÖZET}

Amaç

Bu çalışma ile stres tip idrar kaçırması (STiK) ve pelvik organ prolapsusu (POP) olan hastalarda transobturator tape (TOT) ile eş zamanlı sistosel onarımının operasyon sonuçları üzerine olan etkisi değerlendirildi.

Gereç ve Yöntem

2006-2012 yılları arasında STiK ve sistoseli olan 103 hastanın verileri retrospektif olarak değerlendirildi. Yalnız TOT uygulanan hastalar grup 1, TOT ile eş zamanlı sistosel onarımı yapılan hastalar grup 2 olarak belirlendi. Grup 2 hastalar, düşük evre sistoseli (evre 1 ve 2) olan hastalar grup 2a ve yüksek evre sistoseli (evre 3) olan hastalar grup $2 b$ şeklinde ayrıldı. - Hasta kayıtlarından hastaların yaşları, normal doğum sayıları, ped testi, sistosel evresi, postoperatif komplikasyonlar ve preop International Consultation on Incontinence Questionnaire-Short Form (ICIQ-SF) formları değerlendirildi. Bütün hastalar son kontinans durumları açısından ICIQ-SF ile sorgulandı. Gruplar yukarıdaki parametreler açısından karşılaştırıldı.

Bulgular

Grup 1 ve grup 2 arasında preoperatif ICIQ-SF skorları arasında (sırasıyla $16,06 \pm 0,34$ ve $16,82 \pm 0,42$ ) ve başlangıçtaki değerlendirilen demografik verileri değerlendirildiğinde belirgin bir fark olmadığı görüldü. Postoperatif ICIQ-SF skorlarının ise her iki grupta da belirgin olarak düştüğü görüldü (sırasıyla, $3,28 \pm 0,78$ ve $5,41 \pm 1,21, p<0,01$ ). Grup $2 b$ hastalarda grup $2 a$ hastalara göre preoperatif ICIQ-SF değerlerinde fark yokken postoperatif

\section{Correspondence}

Ozan Bozkurt MD, Dokuz Eylül University Faculty of Medicine, Department of Urology, İzmir, Turkey

Phone: +90 2324123450 E-mail: drozanbozkurt@gmail.com

Journal of Urological Surgery. 


\section{ABSTRACT}

was significantly lower. The mean $\triangle \mathrm{IClQ}-\mathrm{SF}$ score was found to be lower in the patients in group 2a compared to the patients in group 1 and group $2 b$ $(8.88 \pm 1.98,12.77 \pm 0.83$, and $13.57 \pm 1.42$, respectively, $p<0.01)$.

\section{Conclusion}

Conclusively, cystocele repair performed simultaneously with TOT does not provide additional improvement in patients with low grade cystocele, whereas cystocele repair performed simultaneously with TOT provides a more prominent improvement in patients with high grade cystocele.

\section{Key Words}

Urinary incontinence; cystocele; stress urinary incontinance; Transobturator tape (TOT)

\section{ÖZET}

ICIQ-SF skoru anlamlı derecede daha düşüktü, ortalama $\triangle \mathrm{ICIQ}$-SF skoru ise grup 2a hastalarda grup 1 ve grup $2 b$ hastalara göre daha düşük saptandı (sırasıyla $8,88 \pm 1,98,12,77 \pm 0,83$ ve $13,57 \pm 1,42, p<0,01$ ).

\section{Sonuç}

Sonuç olarak düşük evre sistoseli olan hastalarda TOT ile eş zamanlı sistosel onarımı ek düzelme sağlamazken yüksek evre sistoseli olanlarda TOT ile eş zamanlı sistosel onarımı hastalarda daha belirgin düzelme sağlamaktadır.

\section{Anahtar Kelimeler}

Üriner inkontinans, sistosel, stres tip idrar kaçırma, transobturator tape (TOT)

\section{Introduction}

Stress urinary incontinence (SUI) and pelvic organ prolapsus is an important health problem in the elderly population (1). In surgical treatment of SUI, midurethral sling operations including transobturator tape (TOT) and transvajinal tape (TVT) are currently standard methods with proven efficiency and safety (2). The incidence of simultaneous presence of cystocele in patients with SUI in whom midurethral sling operations including TOT and TVT will be performed ranges between $42 \%$ and $57 \%(3,4)$. In such cases, cystocele repair performed simultaneously with midurethral sling operation may increase the success of surgery (5). When cystocele repair is not performed simultaneously, change in the urethral angle may develop postoperatively and the patients may present again with postoperative micturation difficulty or urethral obstruction $(5,6)$. In addition, an increase in the complications including infection, vaginal erosion, increase in blood loss, anatomical disturbance and micturation disturbance or urethral obstructions was observed (7). Therefore, patients should be evaluated carefully and the risk of surgical complications and the benefits of cystocele repair should be absolutely considered. In previous studies, cystocele repair with TVT was evaluated. In a study in which TOT and cystocele repair were evaluated in association, complication rates were compared by incision type (8). In the literature, there is no study evaluating the results of performing TOT and cystocele repair in association in patients with SUI and accompanying cystocele and the surgical success by way of the International Consultation on Incontinence Questionnaire-Short Form (ICIQ-SF).

Our aim in this study was to evaluate the long-term results of the patients who underwent TOT because of SUI using the ICIQ-SF form and investigate the effect of simultaneous cystocele repair on the results of surgery.

\section{Materials and Methods}

The female patients who underwent TOT in our clinic between 2006 and 2013 because of STI were evaluated retrospectively. The patients files were examined and the age, history of vaginal delivery, previous gynecological and vaginal operations, accompanying comorbidities, presence of cystocele and rectocele and their grades, type of incontinence, pad usage, postoperative complications and preoperative ICIQ-SF form were analyzed retrospectively. All patients were questioned in terms of long-term complications and final continence status using the ICIQ-SF form. The patients with accompanying cystocele who underwent TOT alone were classified as group 1 and the patients who underwent cystocele simultaneously with TOT were classified as group 2. The patients who underwent cystocele repair simultaneosly with TOT (group 2) were divided into two groups as group 2a (low grade, grade 1 and 2 cystocele) and grup $2 b$ (high grade, grade 3 cystocele). The preoperative and postoperative ICIQ-SF scores of all patients were compared. The patients in group 1, group $2 \mathrm{a}$ and group $2 \mathrm{~b}$ were compared in terms of postoperative ICIQ-SF and $\triangle \mathrm{ICIQ}$-SF (Preoperative ICIQ-SF-Postoperative ICIQ-SF) values and complications.

\section{Statistics}

Primarily, the preoperative and postoperative data of all patients according to the questions in the IClQ-SF form were compared using paired t-test analysis. Afterwards, the patients in group 1 and group 2 were evaluated according to the ICIO (preoperative, postoperative and $\Delta$ ) data using t-test analysis. Finally, the patients in group 1, group 2a and group $2 b$ were evaluated within themselves according to the ICIO (preoperative, postoperative and $\Delta$ ) data using Mann-Whitney $U$ test.

\section{Results}

A total of 165 female patients were evaluated. The preoperative properties and general information belonging to the patients are given in Table 1.40 patients $(24,2 \%)$ had pure stress urinary incontinence and 125 patients (75.8\%) had mixed type incontinence with predominant stress type. Cystocele was found in 103 patients (35\% grade 1, 40.8\% grade 2 and 24.2\% grade 3); rectocele was found in 40 patients (50\% grade 1,42.5\% grade 2 and $7.5 \%$ grade 3 ). $62.4 \%$ of the patients (103/165) had at least one of the comorbidities including hypertension (HT), diabetes emllitus (DM), chronic obstructive lung disease (COLD), coronary artery disease 
(CAD) and goitre. In a mean follow-up period of 45.1 months (3.598 months), $63.2 \%$ of the patients were found to be completely dry at the final evaluation $(\mathrm{ICIQ}-\mathrm{SF} 3=0)$ and significant improvement was observed in all ICIO-SF scores (Table 2). The rate of complications was found to be $7.8 \% ; 2$ patients had dyspareunia, 7 patients had vaginal erosion, 1 patient had micturation dysfunction, 1 patient had

Table 1. Preoperative general information about the patients who underwent Transobturator tape

\begin{tabular}{|l|l|}
\hline$n$ & 165 \\
\hline Mean age (years) & $56.3 \pm 11.2$ \\
\hline Mean follow-up time (Months) & $45.1 \pm 19.9$ \\
\hline Mean pad usage (/day) & $3.14 \pm 1.93$ \\
\hline Mean number of vaginal deliveries & $2.86 \pm 1.97$ \\
\hline $\begin{array}{l}\text { History of gynecological surgery } \\
\text { (abdominal or vaginal) }\end{array}$ & $21.6 \%$ \\
\hline Grade 1-3 cystocele & $62.4 \%$ \\
\hline Grade 1-3 rectocele & $24.2 \%$ \\
\hline
\end{tabular}

Table 2. Comparison of preoperative and postoperative ICIQ-SF scores in the patients who underwent Transobturator tape

\begin{tabular}{|l|l|l|l|}
\hline & Preoperative & Postoperative & $p$ \\
\hline ICIQ-SF - 3 & $4.05 \pm 0.77$ & $1.32 \pm 1.84$ & $<0.001$ \\
\hline ICIQ-SF - 4 & $4.39 \pm 1.11$ & $1.46 \pm 2.00$ & $<0.001$ \\
\hline ICIQ-SF - 5 & $7.96 \pm 1.12$ & $2.71 \pm 3.56$ & $<0.001$ \\
\hline ICIQ-SF - Total & $16.41 \pm 2.70$ & $5.49 \pm 7.34$ & $<0.001$ \\
\hline
\end{tabular}

Table 3. Comparison of ICIO-SF scores in both groups in patients with cystocele

\begin{tabular}{|c|c|c|c|}
\hline & $\begin{array}{l}\text { Group } 1 \\
\text { TOT alone } \\
(n=62)\end{array}$ & $\begin{array}{l}\text { Group } 2 \\
\text { TOT+Custocelel } \\
(n=41)\end{array}$ & $P$ \\
\hline Preoperative ICIO-SF & $16.06 \pm 0.34$ & $16.82 \pm 0.42$ & 0.395 \\
\hline Postoperative ICIQ-SF & $3.28 \pm 0.78$ & $5.41 \pm 1.21$ & 0.004 \\
\hline$\triangle \mathrm{ICIQ}-\mathrm{SF}$ & $12.77 \pm 0.83$ & $11.41 \pm 1.23$ & 0.017 \\
\hline
\end{tabular}

bleeding and 2 patients had vaginitis. No intraoperative complication was observed. The patients who had vaginal erosion were treated with partial tape excision and primary closure under local anesthesia. When group 1 and 2 were compared, the mean age (57.77 \pm 1.43 vs. $55.78 \pm 1.66, p=0.503)$ and number of vaginal deliveries $(3.19 \pm 0.30$ vs. $2.88 \pm 0.25, p=0.143$ ) were similar; the mean rate of usage of daily pad was slightly higher in group $1(3.34 \pm 0,28$ vs. $3.21 \pm 0.26, p=0.047)$. There was no marked difference between preoerative ICIQ-SF scores. It was observed that the postoperative ICIQ-SF scores significantly decreased both in group 1 and group $2(p<0.001)$, The $\triangle I C I Q-S F$ score was found to be significantly higher in group 1 compared to group 2 (Table 3). While there was no difference in preoperative ICIQ-SF values in the patients with high-grade cystocele compared to the patients with low-grade cystocele, the mean postoperative ICIQ-SF score was significantly lower. The mean $\triangle \mathrm{ICIQ}$-SF score was found to be lower in the patients with low-grade cystocele compared to the group with TOT alone (group 1) and the patients with high-grade cystocele (group 2b) (Table 4).

\section{Discussion}

An increase in anatomical problems which require surgery including cystocele and SUI occurs with advanced age in women. $11.1 \%$ of women aged 80 years require surgery because of SUI. More than one surgical procedure are performed in 29.2\% of these women (9). In most of the patients with SUI who require surgical treatment, cystocele which also requires surgical treatment is present $(3,4)$. The risks and postoperative benefits of surgery should be considered in patients who will undergo cystocele repair simultaneously with midurethral sling operation. As mentioned above, presence of cystocele may affect the success of midurethral sling operation by acting on micturation function $(5,6)$. In addition, it is known that presence of cystocele is an important risk factor for failure in patients who will undergo midurethral sling operation because of SIU $(5,6)$. In one study, it was shown that resistant micturation defects were present after sling operation in patients with high-grade cystocele $(5,6)$. In another study, it was found that simultaneous cystocele repair had no effect on the success of surgery in the patients who had low grade cystocele compared to the patients who underwent only TVT (6). In other similar studies, similar findings were observed $(10,11)$. In addition, it was reported that presence of low-grade cystocele had no effect on the success of sling independent of cystocele repair (6). Studies have reported the complication rate following operation to range between $10 \%$ and $20 \%$ in patients who underwent cystocele

Table 4. Comparison of the patients with low grade and high grade cystocele in group 2 with the patients in group 1

\begin{tabular}{|c|c|c|c|c|}
\hline & \multirow[t]{2}{*}{$\begin{array}{l}\text { Group } 1 \text { TOT alone } \\
(n=62)\end{array}$} & \multicolumn{2}{|c|}{$\begin{array}{l}\text { Group } 2 \text { TOT+Cystocele } \\
\qquad(n=41)\end{array}$} & \multirow[b]{2}{*}{$p$} \\
\hline & & $\begin{array}{l}\text { Patients with low grade cystocele } \\
\text { (group } 2 a)(n=19)\end{array}$ & $\begin{array}{l}\text { Patients with high grade cystocele } \\
\text { (group } 2 b)(n=22)\end{array}$ & \\
\hline Preoperative ICIQ-SF & $16.06 \pm 0.34$ & $16.00 \pm 0.69$ & $17.52 \pm 0.47$ & 0.899 \\
\hline Postoperative ICIQ-SF & $3.28 \pm 0.78$ & $7.11 \pm 1.99$ & $3.95 \pm 1.44$ & $<0.001^{*}$ \\
\hline$\triangle \mathrm{IClQ}-\mathrm{SF}$ & $12.77 \pm 0.83$ & $8.88 \pm 1.98$ & $13.57 \pm 1.42$ & $0.002^{*}$ \\
\hline
\end{tabular}


repair or midurethral sling operation because of SUI $(12,13)$. In our series, the rate of complications was found to be $7.8 \%$. The difference in the rates of complications may be related with the fact that cystocele repair performed simultaneously with TVT was evaluated in most previous studies, whereas TOT was performed as midurethral sling operation in our study. In previous studies, the incidence of simultaneous presence of cystocele was reported to range between $42 \%$ and $57 \%$ in patients with SIU who would undergo TVT $(3,4)$. This rate was found to be $62.4 \%$ in our study. In a study performed previously, the effect of simultaneous cystocele repair in presence of low-grade cystocele on the success of TVT was evaluated by urodynamic examination and no significant effect on the success of surgery was shown (6). Again in this study, no complication occured in the group who underwent TVT alone, while vaginal erosion was found with a rate of $4.3 \%$ in the group who underwent TVT+cystocele repair. In our study, the success results were assessed by the ICIQ-SF form applied before operation and at the end of a long follow-up period which lasted for 45.1 months when evaluating the surgical success. Among the patients who underwent TOT + cystocele repair, the surgical success rate was found to be significantly higher in the patients with hig-grade cystocele compared with the patients with low-grade cystocele. However, simultaneous cystocele repair was not found to have an additional effect on the success of TOT in the group with low-grade cystocele.

Considering improvement in the ICIQ-SF scores in the long-term, TOT surgery performed in daily practice provides a high level of satisfaction in terms of patients and can be performed safely despite accompanying comorbidities. In addition, cystocele repair performed simultaneously with TOT did not provide additional improvement in the ICIQ-SF score compared to TOT alone in the patients with lowgrade cystocele, whereas it provided a more prominent improvement compared to TOT alone in the patients with high-grade cystocele.

\section{References}

1. Boreham MK, Wai CY, Miller RT, Schaffer Jl, Word RA. Morphometric analysis of smooth muscle in the anterior vaginal wall of women with pelvic organ prolapse. Am J Obstet Gynecol 2002;187:56-63.
2. Lucas MG, Bosch RJ, Burkhard FC, Cruz F, Madden TB, Nambiar AK, Neisius A, de Ridder DJ, Tubaro A, Turner WH, Pickard RS. EAU guidelines on surgical treatment of urinary incontinence. European Association of Urology. Actas Urol Esp 2013Sep;37(8):459-472. doi: 10.1016/j. acuro.2013.02.002.

3. $\mathrm{Ng} \mathrm{CS}$, Rackley RR, Appell RA. Incidence of concomitant procedures for pelvic organ prolapse and reconstruction in women who undergo surgery for stress urinary incontinence. Urology 2001;57(5):911-913.

4. Morgan TO, Westney OL, McGuire EJ. Pubovaginal sling: 4-year outcome analysis and quality of life assessment. J Urol 2000;163(6):1845-1848.

5. Paick JS, Cho MC, Oh SJ, Kim SW, Ku JH. Factors influencing the outcome of mid urethral sling procedures for female urinary incontinence. J Urol 2007;178(3):985-989.

6. Park HK, Paick SH, Lho YS, Choo GY, Kim HG, Choi J. Lack of effect of concomitant stage II cystocele repair on lower urinary tract symptoms and surgical outcome after tension-free vaginal tape procedure: randomized controlled trial. Int Urogynecol J 2013;24:1123-1126.

7. Wein AJ, Kavoussi LR, Novick AC, Partin AW, Peters CA. Campbell-Walsh Urology, 9th ed. Philadelphia, SaundersCtElsevier, 2007.

8. Yonguc T, Bozkurt IH, Arslan B, Kozacioglu Z, Gulden I, Gunlusoy B, Degirmenci T. Outcomes of two different incision techniques for surgical treatment of stress urinary incontinence with concomitant anterior vaginal wall prolapse. World J Urol 2014;Aug 31.

9. Olsen AL, Smith VJ, Bergstrom JO, Colling JC, Clark AL. Epidemiology of surgically managed pelvic organ prolapse and urinary incontinence. Obstet Gynecol 1997;89(4):501-506.

10. Deffieux $X$, Daher $N$, Mansoor A, Debodinance $P$, Muhlstein J, Fernandez H. Transobturator TVT-O versus retropubic TVT: results of a multicenter randomized controlled trial at 24 months follow-up. Int Urogynecol J 2010;21(11):1337-1345.

11. Reich A, Kohorst F, Kreienberg R, Flock F. Long-term results of the tensionfree vaginal tape procedure in an unselected group: a 7-year follow-up study. Urology 2011;78(4):774-777.

12. Ignjatovic I, Stojkovic I, Basic D, Medojevic N, Potic M. Optimal primary minimally invasive treatment for patients with stress urinary incontinence and symptomatic pelvic organ prolapse: tension free slings with colporrhaphy, or Prolift with the tension free midurethral sling? Eur J Obstet Gynecol Reprod Biol 2010;150(1):97-101.

13. Deffieux $X$, de Tayrac R, Huel C, Bottero J, Gervaise A, Bonnet $K$, Frydman R, Fernandez $H$. Vaginal mesh erosion after transvaginal repair of cystocele using Gynemesh or Gynemesh- Soft in 138 women: a comparative study. Int Urogynecol J Pelvic Floor Dysfunct 2007;18(1):73-79. 